Tempering Growth: Planning for the Challenges of Climate Change and Growth Management in SEQ

Ayşın Dedekorkut ${ }^{\mathrm{a} *}$, Johanna Mustelin $^{\mathrm{b}}$, Michael Howes $^{\mathrm{a}}$ and Jason Byrne ${ }^{\mathrm{a}}$

${ }^{\mathrm{a}}$ Griffith School of Environment \& Urban Research Program, Gold Coast Campus, Griffith University, Queensland, Australia;

${ }^{\mathrm{b}}$ Griffith Centre for Coastal Management \& South East Queensland Climate Adaptation Research Initiative, Gold Coast Campus, Griffith University, Queensland, Australia

*Corresponding author. Email: a.dedekorkut@griffith.edu.au 


\title{
Tempering Growth: Planning for the Challenges of Climate Change and Growth Management in SEQ
}

\begin{abstract}
South East Queensland (SEQ) has experienced voracious growth over the past five decades. Spanning some $200 \mathrm{~km}$, this sprawling subtropical coastal conurbation is beginning to reach its ecological and socio-political limits. Over the last decade there have been concerted efforts to manage this growth with a new regime of plans and policies, but climate change has significantly complicated the challenge. This paper offers a preliminary analysis of the situation. The major climate adaptation challenges for the region are identified, including: rising sea levels, storm surges, higher temperatures, and increased freshwater scarcity. These will impact most on the elderly, sick and disadvantaged who have lower levels of resilience. The key plans and policies that address these issues are then reviewed, including: Climate $Q$; the SEQ Regional Plan; and, the Draft SEQ Climate Change Management Plan. The overall planning regime is appraised in light of five core themes of strong ecological modernisation (technological innovation; engaging with economic imperatives; political and institutional change; transforming the role of social movements and discursive change) and the principles of environmental justice. It is argued that together these schools of thought could provide criteria for a more effective and equitable climate adaptation response for the region.
\end{abstract}

Keywords: climate change adaptation; ecological modernisation; environmental justice; South East Queensland; growth management

\section{Introduction}

Managing rapid population growth and development is difficult at the best of times, but it becomes even more challenging for regions that are highly vulnerable to the impacts of climate change. SEQ is a case in point - it has experienced one of the fastest population growth rates in Australia and has been singled out by the Intergovernmental Panel on Climate Change (IPCC) as one of the most vulnerable regions owing to its geography and settlement patterns (Hennessy et al., 2007 in IPCC $4^{\text {th }}$ Assessment Report). This article considers the issue from a new 
perspective through an integrated framework of ecological modernisation and environmental justice. The first section briefly summarises the major impacts of climate change for SEQ. The following two sections then introduce the principles of strong ecological modernisation (EM) and environmental justice (EJ) respectively. The final section evaluates some of the key policies and plans that purportedly address the problem, utilising these two frameworks. Overall it is argued that an effective response will require more than just engineering solutions. It demands an integrated approach that includes technological and institutional transformations that equitably engage with key stakeholders.

\section{Impacts of Climate Change in SEQ}

Climate change projections for SEQ include: significant sea level rise; increased storm surges; more frequent and intense extreme weather events; higher temperatures and evaporation; and, decreasing precipitation. Sea level rise and storm surges pose serious threats of inundation and coastal erosion. The concentration of a large population in vulnerable areas along the coastal creeks and rivers exposes the highest number of properties in all Australia to flooding (OCC, 2008). Every coastal local government area in SEQ is among the top ten areas at risk of inundation in Queensland. The Commonwealth Scientific and Industrial Research Organisation (CSIRO) estimates that climate change will increase current levels of risk of inundation in SEQ to affect a larger percentage of the population and residential buildings and increase the cost of structure and content damage substantially (DCC, 2009). Furthermore, over $70 \%$ of commercial buildings in SEQ are currently located within five $\mathrm{km}$ of the shoreline. CSIRO researchers conclude that not only do planning and building regulations need to be strengthened to stop further high risk development, the existing building stock also needs to be adapted and/or protected (DCC, 2009).

Natural hazards are already raising costs in the region in terms of increased insurance claims, coastal management works, infrastructure maintenance, and emergency services. With climate change, severe tropical cyclones (categories 3-5) on the east Australian coast are predicted to increase in frequency and cyclone 
development regions are projected to shift $200 \mathrm{~km}$ southwards, resulting in greater exposure in SEQ (Hennessy et al., 2007). Storm tides occur mostly due to tropical cyclones and mid-latitude depressions and so are likely to increase in the SEQ coastal region (McInnes et al., 2000). The intensity of extreme rainfall events (Hennessy et al., 2007), hail-days per year (OCC, 2008) and the incidence of bushfires (Burton, 2005) are also projected to increase in coming decades.

Temperature projections for SEQ show a rise in the number of days over $35^{\circ} \mathrm{C}$. The projected annual average temperature increases for the region are between $2.5-4^{\circ} \mathrm{C}$ by 2070 (DERM, 2009a). These changes will have significant health impacts, including heat exhaustion and increased mortality among vulnerable sectors of the community, such as the very young or old (McMichael et al., 2003). Higher temperatures will also affect peak energy demand, with greater reliance on airconditioning to achieve thermal comfort.

Annual potential evaporation of freshwater supplies in SEQ is projected to increase $2-8 \%$ by 2050 and $6-16 \%$ by 2070 . To make the matters worse, total annual rainfall is projected to decrease between 3-8\%, the largest reduction expected in Queensland (DERM, 2009a). The impacts on agricultural production will be significant with crop yields and quality declining. Reyenga et al. (1999, p. 297) predict that 'the status of the region as a producer of prime hard wheat may be at risk'. Similarly, drier conditions are expected to reduce plant and animal production in the grazing industry (Howden et al., 1999). Increased pest and disease risks are among the predicted impacts (OCC, 2008; DCC, 2009). Despite these scenarios, the burden of these impacts will likely be uneven, with certain industries and communities more vulnerable than others. Government policy and research support is urgently required but as the following analysis shows, efforts to date are problematic.

\section{Rethinking the Problem with Ecological Modernisation (EM)}

The impacts of climate change on SEQ will require an effective response from government. Some policies and plans are beginning to acknowledge the problem, but what criteria should be used to guide and assess the response? Two key schools of thought could provide an answer. First are criteria that can be derived from the core 
themes of EM and will be dealt with in this section. Second is the criterion of equity that is central to environmental justice and will be dealt with in the next section.

EM is a broad school of thought based on the assumption that capitalism and its associated industrial mode of production and democratic forms of government can be moved onto a trajectory of more sustainable development. The process for achieving this transformation involves the deployment of ecologically efficient technology and varying degrees of institutional restructuring. At its heart, EM advocates a green industrial revolution to support a second phase of modernisation - one that is ecologically sustainable (Beck, 2010). The idea emerged from the work of German scholars such as Martin Janicke and Joseph Huber, among others, in the early 1980s (Hajer, 1995; Weale, 1998; Mol and Sonnenfeld, 2000; Mol and Spaargaren, 2000; Huber 2000 and 2008; Grant and Papadakis, 2004; Janicke and Jacob 2004; Janicke, 2008). While EM has clear implications for climate mitigation (Bulkeley 2001; Christoff 2005; Curran 2009), in Australia very little work has been done applying the concept to adaptation policies and plans (Byrne et al., 2009).

EM ranges from weak variants that focus on a limited range of technological fixes to more reflexive theories that advocate the establishment of a a broader system of ecological democracy (Christoff, 1996; Fisher and Freudenburg, 2001; Dryzek, 2005). This paper will use the strong version of EM because it offers a greater scope for action on climate change. Five core themes have been derived by previous EM work: technological innovation; engaging with economic imperatives; political and institutional change; transforming the role of social movements and discursive change (Berger et al., 2001 and Welford and Hills, 2003; Howes et al., 2010). These themes provide both an integrated analytical framework and a program for action. It should be noted, however, that care must be taken in transplanting EM from its predominantly German roots to the Australian context as the countries have significantly different economic, political and social contexts (Curran, 2009; Howes et. al., 2010).

The theme of technological innovation is to encourage the research, development and deployment of new technologies that make more efficient use of resources and reduce their negative environmental impacts (Fisher and Freudenburg 2001; Berger et. al., 
2001; Cohen, 2006; Huber 2008). For adaptation, this means promoting research into urban design, infrastructure, and building to improve resilience to flooding, storms, higher temperatures, bushfires or water scarcity, while also moving planning mechanisms towards more flexible and innovative decision-making frameworks.

In terms of engaging with economic imperatives, the objective is to harness market forces and steer them down a sustainable development path. This involves using government policies and plans to create incentives for more sustainable behaviour and engaging businesses as partners in developing a response (Gouldson and Murphy, 1997; Mol, 2000; Mol and Sonnenfeld, 2000; Mol and Spaargaren, 2000; Berger et. al., 2001; Huber, 2008). For adaptation, this will have a particular application to property developers and the construction industry more generally.

EM suggests that effective responses to environmental issues need to be hardwired into the political decision making process, and this will require some institutional restructuring. Government is seen as playing a central role in the transition to sustainability, but it needs to be more open and decentralised to maximise civic participation. Public consultations should be regular and 'real', moving beyond simple window dressing (Gouldson and Murphy, 1997; Mol, 2000; Mol and Sonnenfeld, 2000; Mol and Spaargaren, 2000; Janicke and Jacob 2004; Janicke, 2008).

On a related point, transforming the role of social movements means empowering community groups that have previously been left outside the decision making process so that they can constructively engage with government and become partners in implementing solutions. Sustainability is not something that governments can achieve alone as it requires the cooperation of both the business and community sectors (Hajer, 1995; Mol, 2000; Mol and Sonnenfeld, 2000; Fisher and Freudenburg, 2001). It is a two-way street where governments become more responsive to community needs and the community shoulders some of the effort in making the necessary changes. This also requires enhanced transparency in decision-making processes.

The final theme of EM is discursive change. The rhetoric of 'jobs versus the environment' is replaced by a 'win-win scenario' and environmental problems are reconstructed as challenges or opportunities for improvement (Christoff 1996; 
Gouldson and Murphy, 1997; Mol, 2000; Mol and Sonnenfeld, 2000; Mol and Spaargaren, 2000; Berger et. al., 2001; Dryzek, 2005; Howes et. al., 2010). In terms of climate adaptation, the up-front costs are readily apparent, but what might be the opportunities? One possibility is to see adaptation as an opportunity to instigate a systematic process of urban renewal and 'green modernisation'. While the core themes of EM can provide some guidance with regards to technical and institutional change, we also need to consider the environmental equity dimensions of any response. This is where the idea of environmental justice can help.

\section{The Environmental Justice (EJ) Dimension}

Governments have tended to favour technocratic solutions to anticipated climate change impacts (e.g. modelling sea level rise, building sea-walls and adopting green building guidelines and standards) over socio-political engagement and reform (Byrne et al., 2009; Thomas, 2010). Seeking to manage urban sprawl through compact development - also termed 'smart growth' - has been a favoured policy response (Brown and Southworth, 2008; Hamin and Gurran, 2008; Ruth, 2006). What seems to be missing though, is any consideration of how the various forms of 'difference' which can configure vulnerability or resilience (e.g. gender, class, race, ethnicity, disability, etc.) may disproportionately focus some climate change impacts upon groups of people who may be least able to resist or adapt to them (Bolin, 2006; Conner, 2005; Denton, 2002). Poorly designed growth management policies might even exacerbate these impacts. The fact that marginalised and vulnerable people will

likely suffer disproportionately from climate change impacts constitutes an 'environmental inequality' warranting urgent attention (Campbell et al., 2008; Green, 2006; Mendelsohn et al., 2006).

'Environmental justice' is both a social movement and a research frame. As a social movement it grew out of the United States (US) Civil Rights Movement of the 1960s, and gained public attention during the early to mid 1980s when various non-white communities in the US produced compelling evidence that their neighbourhoods were disproportionately burdened by environmental harms from waste incinerators, toxic landfill sites, chemical waste from large-scale industrial plants, poisoning from farm 
pesticides and herbicides and the like (Bullard, 1993; Taylor, 2000). Both community activists and academic researchers in the US have since produced irrefutable arguments that low-income earners (i.e. people below the poverty line and the working poor) and non-whites (e.g. African-Americans, indigenous peoples) pay the highest price of urban growth (Agyeman, 2005; Bullard, 2007). Similar patterns of environmental inequality have since been found in Australia (e.g. Arcioni and Mitchell, 2005; Lloyd-Smith and Bell, 2003) and indeed globally (Shiva, 1999). While the impacts are usually obvious (e.g. high rates of infant mortality, elevated levels of respiratory disease, coronary heart disease and cancer), the processes behind environmental inequality are rarely simple; the topic has been the subject of considerable debate (Byrne, 2010).

Climate change presents some profound environmental justice challenges. As Kaswan (2008) notes, it will impact more severely upon people who are impoverished, who are unable to participate in decision-making about change in their communities, who are politically disenfranchised and who - perhaps because they are recent migrants lack language skills and social connections (Byravan et al., 2006; Salick et al., 2007). While wealthy residents may be able to escape impacts because they can afford to live in cooler places, to install insulation and air-conditioners, to relocate, or to pay higher insurance premiums, these options are not necessarily available to the poor and socially marginalised. These disadvantaged communities will instead likely be burdened by new diseases, poor quality housing in hotter locations, water and food shortages, flooding and storm damage among other problems - a situation that has recently been termed 'climate (in)justice' (Caney, 2009; Frumkin, 2005; Gottlieb and Fisher, 2000; Shonkoff et al., 2009; Sweetman, 2009).

To date, very little policy literature shows that mainstream environmental justice concerns are even on the radar of Australian planners, let alone climate change equity (Arcioni and Mitchell, 2005; Lloyd-Smith and Bell, 2003). The situation in SEQ is little different with only a cursory reference to the inequitable impacts of climate change in the 2009 Regional Plan (DIP, 2009a, p. 78-88), but this may be about to change. A recent study of climate change and health impacts on the Gold Coast (Baum et al., 2009) found that income, age and social isolation were significant factors in predicting the likelihood that an individual would be vulnerable to the 
impacts of flooding and higher urban temperatures. Studies of this kind constitute a first step in better understanding how socioeconomic vulnerability might lead to increased exposure to climate change impacts in the absence of land use policy interventions. From here, we need to research how growth management policies such as urban consolidation might spatially concentrate low income and socially marginalised groups in hazardous locations.

\section{Review of Plans and Policies}

A multiplicity of existing plans and policies already claim to address issues resulting from the rapid pace of growth and a changing climate in SEQ. This section provides a brief overview of a selection of the most relevant of these regarding adapting to climate change impacts.

\subsection{National Policies}

The Australian Government views adaptation as one of the three pillars of its comprehensive climate change strategy, along with mitigation to reduce Australia's greenhouse gas emissions, and helping shape a global response to the problem. In April 2007, the Council of Australian Governments agreed to the National Climate Change Adaptation Framework (COAG, 2007) which outlines the future agenda of collaboration between governments and will guide action over the next five to seven years. The focus of the Framework is to address key demands from business and the community for targeted information on climate change impacts and adaptation options. Most of the activities resulting from the Framework focus on facilitating, coordinating and disseminating the results of research.

\subsection{Queensland State Policies}

Three main documents guide state policy in addressing the issue of climate change. Toward Q2: Tomorrow's Queensland (Department of the Premier and Cabinet, 2008) is a state plan developed to tackle the challenges of rapid population growth and climate change. It focuses mainly on mitigation measures to reduce greenhouse gas 
emissions and sets a target to cut Queenslanders' carbon footprint by one-third through reduced car and electricity use by 2020 .

ClimateQ: Toward a Greener Queensland (DERM, 2009a) is the state strategy that sets a framework for transitioning to a more sustainable economy. It consolidates and updates ClimateSmart 2050 - Queensland Climate Change Strategy 2007: A Low Carbon Future; and, Queensland's ClimateSmart Adaptation 2007-12: An Action Plan for Managing the Impacts of Climate Change. The adaptation plan includes 62 actions in the areas of water planning and services, agriculture, human settlements, natural environment and landscapes, emergency services and human health and tourism, business and industry. Most of these focus on research (data collection, analysis and sharing) and capacity building activities. Three of the five key themes of Climate $Q$ have adaptation elements: investing in the productive future of key industries, conserving significant ecosystems and adapting to the impacts of climate change. In terms of specific adaptation investments and policies Climate $Q$ focuses on the areas of disaster management, water use efficiency, biodiversity protection and research.

The 2009 Draft Queensland Coastal Plan (DERM, 2009b) is a revision of the 2001 plan and addresses planning for future urban development in and near coastal locations. The draft puts more emphasis on dealing with coastal hazards, such as erosion and sea-level rise, and managing the pressures of population and development. Pursuing the objectives of the Coastal Protection and Management Act of 1995, the draft plan protects coastal resources by setting out criteria for land-use planning and development assessment. It aims to keep coastal hazard risk areas free of permanent development by not allocating new land for future urban development within such areas. It also includes measures to ensure that development is designed and located to minimise coastal hazard risks for developments that must occur within coastal hazard areas and in areas where previous urban development allocations were made. The draft plan will inform regional plans, local government planning schemes and decisions on development applications as well as provide detailed guidance on how to design and locate development to avoid coastal hazard risks. The determination of areas prone to erosion and storm tide inundation takes climate change impacts (such as sea level rise and projected increases in cyclone intensity) 
into account. When adopted, the plan will become a statutory instrument under the Coastal Protection and Management Act of 1995.

\subsection{Regional Policies}

Regional planning in SEQ was guided by a series of voluntary, collaboratively derived, Regional Frameworks for Growth Management (RFGM) from 1990 to 2005, but no climate change issues were specified. In 2005 the last RFGM gave way to the statutory SEQ Regional Plan (OUM, 2005) which, for the first time, recognised climate change but included only very general mitigation principles. The 2005 plan was reviewed and revised ahead of schedule due to higher than expected population growth and the increasingly urgent need to respond to climate change. Recognising that SEQ has been identified by the IPCC (Hennessy et al., 2007 in the IPCC fourth Assessment Report) as a climate change "hot spot", the Queensland Government made climate change a key focus of this review. The 2009 Plan (DIP, 2009a) sets out a regional vision for SEQ that is sustainable, affordable, prosperous, liveable and resilient to climate change. The plan offers a specific regional policy on 'Sustainability and Climate Change' by developing adaptation strategies and protecting areas at risk. Reducing greenhouse gas emissions and energy demand are the mitigation measures. While acknowledging the need for protection from natural hazards, including the effects of climate change, the plan says little on how this should occur. It refers to consistency with the state Coastal Plan and leaves implementation issues to other plans.

The 2009 Regional Plan was drafted under the Queensland framework planning law, the Integrated Planning Act 1997 (IPA). Shortly after the revised Regional Plan came into effect, IPA was replaced by the Sustainable Planning Act (SPA) of 2009. The SEQ Regional Plan 2009-2031 remains in effect under SPA but will be updated to reflect the requirements of the new Act.

The implementation of the SEQ Regional Plan 2009-2031 is supported by several initiatives, including the:

- Draft SEQ Climate Change Management Plan; 
- SEQ Natural Resource Management Plan; and,

- SEQ Rural Futures Strategy.

Each of these initiatives focuses on one specific policy area covered by the regional plan and all are consistent with the desired regional outcomes, principles and policies developed in the regional plan.

The regional plan called for a SEQ Climate Change Management Plan (CCMP) (DIP, 2009b) to identify climate change actions for state and local governments. This aims to establish the region's long-term climate change goals and ensure the region moves to a low-carbon future. The Draft CCMP contains 32 proposed planning actions to reduce emissions and help the region become more resilient to the impacts of climate change. Thirteen of these actions are concerned with natural hazards and climate change adaptation, the rest are mitigation actions. Seven of the 13 adaptive actions propose to review and revise existing plans, policies and guidelines, develop new guidelines and strategies or implement state policies through lower level planning. The remaining six adaptive actions focus on data collection, synthesis and communication. Some of these actions are already under way although the CCMP does not provide detail of how all of these actions will be implemented.

The SEQ Natural Resources Management Plan (NRMP) (DERM, 2009c) is the nonstatutory environment and natural resource management plan for the region and provides measurable regional targets to support the sustainability framework of the SEQ Regional Plan. The NRMP discusses briefly the climate adaptation implications for coastal and marine environments, nature conservation and water categories; however, as stated within the document (DERM, 2009c, p. 4) the 'SEQ NRMP is not a traditional natural resource management plan. It does not include a traditional implementation strategy or contain an extensive list of actions. Rather, it is designed to guide existing and future plans, strategies and actions to coordinate the management and use of natural resources to enhance community, economic and environmental values' (emphasis in the original). Furthermore, most of the "measurable" targets suggest maintaining natural resource quality at a past baseline level or improving from that. 
The Rural Futures Strategy for SEQ 2009 (DIP, 2009c) was prepared as part of the SEQ Regional Plan 2009-2031 to help rural areas meet the challenges of increasing global competition, access to water, availability of skilled labour, climate change and rapid population growth. It proposes actions to improve the triple bottom-line of economic prosperity, environmental wellbeing and quality of life of rural SEQ. The strategy includes a Rural Futures Action Plan, which provides a list of current and planned programs and projects, timelines and responsible organisations under five major themes: economic development, healthy and productive rural landscapes, water resources, community development and leadership and collaboration (the implementation mechanism). The action plan includes strategic actions on climate change adaptation in areas of water resource shortages, loss of biodiversity and loss of agricultural production.

IPA (and its successor SPA) requires other plans to be aligned with the SEQ Regional Plan. While this plan provides the overall strategic direction for SEQ's development, the SEQ Coastal Plan (EPA, 2006) provides more specific direction on coastal management outcomes. As such, the Coastal Plan makes policy links to SEQ Regional Plan explicit. However, since this plan was prepared before the latest regional plan, it has limited reference to climate change. As a result of the review of the previous state coastal plan, the Minister for Sustainability and Climate Change decided to remove the requirement to prepare regional coastal management plans from the Coastal Protection and Management Act 1995. Regional coastal plans will not be in force after the new state Coastal Plan becomes valid (DERM, 2009d). Like the state Coastal Plan, SEQ Coastal Plan is a statutory instrument. The plan discusses mitigation of loss of coastal wetlands as a climate change adaptation strategy but does not go into further detail than suggesting the use of vegetated buffers.

The Revised Draft SEQ Water Strategy (QWC, 2009) is the blueprint to secure the region's long-term water supplies in response to the variable climate and growing population. The Strategy examines alternative water sources and demand management options, and develops a strategic direction for water supply in the region through to 2056. It is part of a suite of regional water policies that contribute to achieving the desired outcomes of the Regional Plan and a number of different agencies are responsible for implementing elements of the Strategy. Key features are: more 
efficient water use; increasing grid water supplies with desalination facilities and other potential water supplies; increasing off-grid local water supplies such as rainwater tanks, stormwater harvesting and recycling; drought planning; and, recycled water. The Strategy was developed with ongoing consideration of climate change, climate variability, population growth and other regional factors affecting supply and demand. It acknowledges the impacts of climate change on the region's water resources, discusses planning for climate change and climate independent and resilient supplies and assumes a reduced availability of water in the future. Climate adaptation specific actions of the strategy focus on data collection and better understanding of the impacts, however, many strategies that do not speak of climate change are nevertheless instrumental to adaptation.

The SEQ Healthy Waterways Strategy 2007-2012 (SEQHWP, 2007) deals with aquatic ecosystem health and water quality issues. It contains measures by which the impacts of human activities on aquatic ecosystems can be avoided or ameliorated. It also includes an integrated set of 12 Action Plans that SEQ Healthy Waterways Partners have committed to undertake between 2007 and 2012. The Partnership includes agencies from all levels of government, industry, research groups, and the community and has a focus on leadership, commitment and voluntary cooperation to understand, plan and manage the use of SEQ's waterways and catchments. The aim is to complement, support and help implement other strategies and plans, including the Regional Plan and natural resource management plans. The Strategy includes separate issue-based action plans regarding point source pollution, non-urban diffuse source pollution, water sensitive urban design, protection and conservation, and coastal algal blooms as well as three enabling and four area-based action plans. Point source pollution, non-urban diffuse source pollution, coastal algal blooms, management strategy evaluation and two of the area-based action plans include some discussion of climate change.

What all these plans, strategies and policies convey is that governments at federal, state and regional levels are at last beginning to recognise and address climate change as an important stressor to be managed by spatial planning. Whether these efforts are sufficient and effective in dealing with the extraordinary challenges the region is facing is another matter. 


\section{So How Well is SEQ Doing?}

So how well do the current SEQ plans and policies fare against the core themes of strong EM and EJ principles in adapting to climate change? Given the multiplicity of plans, and space limitations, only a general overview followed by a preliminary analysis of the two key plans is possible here.

The first steps towards technological innovation (the first theme of EM) have been taken. Research was identified as a key activity by the National Climate Change Adaptation Framework. This was institutionalised by the establishment in 2007 of the National Climate Change Adaptation Research Facility which has been given the task of coordinating research projects around the country via a set of National Climate Change Adaptation Research Plans. The Department of Climate Change has allocated $\$ 30$ million for research into adaptation and the most vulnerable coastal regions have been identified (DCC, 2009). As indicated in previous sections, state and regional plans and policies have strong research elements. And a joint research project, South East Queensland Climate Adaptation Research Initiative, has also been launched to specifically help local governments in determining practical and cost-effective adaptation strategies.

In terms of engaging with economic imperatives, the 2009 SEQ Regional Plan has placed greater emphasis on the issue than its predecessor, with a separate chapter on sustainability and climate change. Unfortunately, adaptation is only allocated two pages, outlining goals for the future. There is a statement suggesting that rural industries might maximise their opportunities, but no detail about how economic incentives might be used to increase resilience. This is a significant gap, which should be addressed by both future policy and research.

When it comes to political and institutional change, there has been a range of public consultations in developing the SEQ Regional Plan and the Draft SEQ CCMP and both mention the need to increase public awareness. But there is little by way of substantive institutional change and decisions continue to be made via the established 
policy and planning processes, rather than any more participatory democratic processes.

Harnessing the transformative role of social movements is perhaps one of the least developed aspects of the adaptation policies and plans. Supporting the community is mentioned in documents like Towards Q2, the SEQ Regional Plan but there is no detail on how this might work. One of the major issues will be deciding who pays for the costs of adaptation. Will homeowners and local businesses agree to pay directly the costs of protecting their assets or will the government provide some assistance through general taxation? If it is the former, the social equity dimension could make it a regressive strategy. This easily laps into arguments about legal liability and technical details, whereas finding opportunities for cooperation will be crucial to maintain liveable environments. These debates must begin now before climate impacts overwhelm the community's ability to respond effectively and collaboratively.

Finally, with regards to discursive change, none of the policies or plans mentioned suggests that the situation offers an opportunity to undertake a major urban renewal. Much of the language is stuck in the rhetoric of bearing the costs of defensive actions rather than making productive investments in positive change.

In terms of environmental justice, the state's ClimateSmart Adaptation strategy does address the particular challenges facing indigenous and vulnerable communities and specifically directs investments (funding, community awareness programs, and infrastructure) towards disadvantaged groups - although many of these initiatives are for remote settlements. Enhancing disaster preparedness has been viewed as a key for stronger communities and cyclone-season information is now available in languages spoken among key migrant groups such as Japanese, Chinese, Italian and Korean. (DERM 2009a).

Other plans include some strategies that might help in addressing environmental equity concerns. For example, the Draft SEQ CCMP (DIP, 2009b) advocates that coastal hazard assessments and maps be produced, which could help in locating those communities and areas that will be most affected. It also encourages energy-efficiency 
guidelines for multi-unit housing with enhanced infrastructure solutions (e.g. solar hot water, lifts). Improvements in multi-unit housing can enhance vulnerable groups' living standards as the wealthy are most likely to have the capacity to own or rent higher quality dwellings. Functional public transport plans are also proposed for local areas to create active and accessible communities. Provision of alternative transport will reduce car-dependence and benefit the disadvantaged groups. However, these strategies were not developed with environmental equity concerns in mind and fall short of addressing this issue. Benefits to disadvantaged groups are neither aimed at nor made explicit and discussed in the plan. This reflects a 'business as usual' approach to planning that needs to change if the region is to adapt equitably to climate change impacts.

Tables 1 and 2 review the climate change adaptation related policies, programs and actions of the SEQ Regional Plan and the Draft CCMP respectively from ecological modernisation and environmental justice perspectives. What the tables show is that neither of the plans have explicit policies addressing ecological modernisation and environmental justice concerns. Some policies have implicit actions, a few have marginal connections, but there is enormous potential for improvement. The plans for which we could not provide the same level of detailed analysis here due to space restrictions are not significantly different.

Insert Table 1 about here

Insert Table 2 about here

\section{Conclusions}

This paper set out to provide a preliminary analysis on the current policy and climate change context for SEQ - a rapidly developing region that is already facing many problems associated with population growth. To add to its woes, the region is highly 
vulnerable to the impacts of climate change. Plans and policies at all levels of government have acknowledged the challenges, but have yet to provide much detail regarding what should be done. This supports the need for urgency in fast-tracking adaptation responses and developing practical adaptation strategies within the region. Strong ecological modernisation suggests that any effective response should entail not just technological innovation, but also a more sustained engagement with economic imperatives, political and institutional reform, a transformation of the role of social movements and discursive change. Some of these are underway through the different policies, albeit in rather weak forms. Further, the principle of environmental justice suggests that climate adaptation responses should consider the differences in both the distribution of impacts and the resilience of affected communities, with more assistance being given to socio-economically disadvantaged marginalised groups. Rethinking the problem and responding using these schools of thought will create the opportunity for more effective and equitable solutions.

\section{References}

Agyeman, J., 2005. Sustainable Communities and the Challenge of Environmental Justice. New York: New York University Press.

Arcioni, E. and Mitchell, G., 2005. Environmental Justice in Australia: When the Rats Became Irate. Environmental Politics. 14, 363-379.

Beck, U., 2010. Climate for change, or how to create a green modernity? Theory, Culture \& Society. 27, 254-266.

Baum, S., Horton, S., Low Choy, D. and Gleeson, B., 2009. Climate Change, Health Impacts and Urban Adaptability: Case Study of Gold Coast City. Brisbane: Griffith University Urban Research Program.

Berger G., Flynn A., Hines F., and Johns, R., 2001. Ecological Modernization as a Basis for Environmental Policy: Current Environmental Discourse and Policy and the Implications on Environmental Supply Chain Management. Innovation. 14 (1), 55-72.

Bolin, B., 2006. Race, Class, Ethnicity, and Disaster Vulnerability. In: H. Rodríguez, E. Quarantelli, and R. Dynes, eds. Handbook of Disaster Research. New York: Springer, 113-129.

Brown, M. A. and Southworth, F., 2008. Mitigating Climate Change through Green Buildings and Smart Growth. Environment and Planning A. 40, 653-675.

Bulkeley, H., 2001. No Regrets? Economy and Environment in Australia's Domestic Climate Change Policy Process. Global Environmental Change, 11 (2), 155169.

Bullard, R. ed., 2007. Growing Smarter: Achieving Livable Communities, Environmental Justice, and Regional Equity. Cambridge: The MIT Press.

Bullard, R. ed., 1993. Confronting Environmental Racism: Voices from the Grassroots. Boston: South End Press. 
Burton, D., 2005. South East Queensland's Approach to Climate Change Mitigation. Queensland Planner. 45 (4), 20-22.

Byravan, S., Rajan, S. and Posner, E., 2006. Providing New Homes for Climate Change Exiles. Climate Policy. 6, 247-252.

Byrne, J. 2010. Environmental justice. In: B. Wharf ed. Encyclopedia of Geography, Thousand Oaks: Sage.

Byrne, J., Gleeson, B., Howes, M. and Steele, W., 2009. Climate Change and Australian Urban Resilience: The Limits of Ecological Modernisation as an Adaptive Strategy. In: S. Davoudi, J. Crawford and A. Mehmood, eds. Planning for Climate Change: Strategies for Mitigation and Adaptation. London: Earthscan, 136-154.

Campbell, D., Stafford Smith, M., Davies, J., Kuipers, P., Wakerman, J. and Mcgregor, M., 2008. Responding to Health Impacts of Climate Change in the Australian Desert. Rural and Remote Health. 8, 1-9.

Caney, S., 2009. Justice and the distribution of greenhouse gas emissions. Journal of Global Ethics. 5, 125-146.

Christoff, P., 1996. Ecological Modernisation, Ecological Modernities. Environmental Politics. 5 (3), 476-500.

Christoff, P., 2005. Policy Autism or Double-Edged Dismissiveness? Australia's Climate Policy under the Howard Government. Global Change, Peace and Security. 17 (1), 29-44.

Cohen M., 2006. Ecological Modernization and its Discontents: The American Environmental Movement's Resistance to an Innovation-Driven Future. Futures 38, 528-547.

Conner, T.A., 2005. Social Vulnerability and Adaptive Capacity to Climate Change Impacts: Identifying Attributes in Two Remote Coastal Communities on Haida Gwaii, British Columbia. Thesis (Master's). University of Victoria, British Columbia.

Council of Australian Governments [COAG], 2007. National Climate Change Adaptation Framework. Canberra.

Curran, G., 2009. Ecological Modernisation and Climate Change in Australia. Environmental Politics. 18 (2), 201-217.

Denton, F., 2002. Climate Change Vulnerability, Impacts, and Adaptation: Why Does Gender Matter? Gender and Development. 10, 10-20.

Department of Climate Change [DCC], 2009. Climate Change Risks to Australia's Coast. Canberra: Department of Climate Change.

Department of Environment and Resource Management [DERM], 2009a. ClimateQ: Toward a Greener Queensland. Brisbane: Queensland Government.

Department of Environment and Resource Management [DERM], 2009b. Draft Queensland Coastal Plan. Brisbane: Queensland Government.

Department of Environment and Resource Management [DERM], 2009c. South East Queensland Natural Resource Management Plan 2009-2031. Brisbane: Queensland Government.

Department of Environment and Resource Management [DERM], 2009d Draft Queensland Coastal Plan-questions and answers, http://www.derm.qld.gov.au/environmental_management/coast_and_oceans/coa stal_management/frequently_asked_questions.html, accessed June 11, 2010.

Department of Infrastructure and Planning [DIP], 2009a. South East Queensland Regional Plan 2009-2031. Brisbane: Queensland Government. 
Department of Infrastructure and Planning [DIP], 2009b. Draft SEQ Climate Change Management Plan. Brisbane: Queensland Government.

Department of Infrastructure and Planning [DIP], 2009c. Rural Futures Strategy for South East Queensland 2009. Brisbane: Queensland Government.

Department of the Premier and Cabinet, 2008. Toward Q2: Tomorrow's Queensland. Brisbane: Queensland Government.

Dryzek, J., 2005. The Politics of the Earth: Environmental Discourses. $2^{\text {nd }}$ ed. Oxford: Oxford University Press.

Environmental Protection Agency [EPA], 2006. Southeast Queensland Regional Coastal Management Plan. Brisbane: Queensland Government.

Fisher D. and Freudenburg W., 2001. Ecological Modernisation and Its Critics: Assessing the Past and Looking Toward the Future. Society and Natural Resources. 14, 701-709.

Frumkin, H., 2005. Health, Equity and the Built Environment. Environmental Health Perspectives. 113, A290-A291.

Gottlieb, R. and Fisher, A., 2000. Community Food Security and Environmental Justice: Converging Paths towards Social Justice and Sustainable Communities. Race, Poverty and the Environment. 7, 18-20.

Gouldson, A. and Murphy J., 1997. Ecological Modernization: Restructuring Industrial Economics. In: M. Jacobs, ed. Greening the Millennium? The New Politics of the Environment. Oxford: Blackwell Publishers, 74-86.

Grant R., and Papadakis E., 2004. Challenges for Global Environmental Diplomacy in Australia and the European Union. Australian Journal of International Affairs. 58 (2), 279-292.

Green, D., 2006. Climate Change Impacts on Remote Indigenous Communities in Northern Australia. Sustainability of Indigenous Communities Conference. Aspendale, Victoria: Commonwealth Scientific Industrial Research Organisation.

Hajer, M., 1995. The Politics of Environmental Discourse: Ecological Modernization and the Policy Process. Oxford: Clarendon Press.

Hamin, E. M. and Gurran, N., 2008. Urban Form and Climate Change: Balancing Adaptation and Mitigation in the U.S. and Australia. Habitat International. 33, 238-245.

Hennessy, K., Fitzharris, B., Bates, B.C., Harvey, N., Howden, S.M., Hughes, L., Salinger J., and Warrick, R., 2007. Australia and New Zealand. In: M.L. Parry, O.F. Canziani, J.P. Palutikof, P.J. van der Linden and C.E. Hanson, eds. Climate Change 2007: Impacts, Adaptation and Vulnerability. Contribution of Working Group II to the Fourth Assessment Report of the Intergovernmental Panel on Climate Change. Cambridge, UK: Cambridge University Press, 507-540.

Howden, S.M., McKeon, G.M., Walker, L., Carter, J.O., Conroy, J.P., Day, K.A., Hall, W.B., Ash, A.J., and Ghannoum, O., 1999. Global Change Impacts on Native Pastures in South-East Queensland, Australia. Environmental Modelling \& Software. 14, 307-316.

Howes, M., McKenzie, M., Gleeson, B., Gray, R., Byrne, J., and Daniels, P., 2010. Adapting the Idea of Ecological Modernisation to the Australian Context. Journal of Integrative Environmental Sciences. 7 (1), 5-22.

Huber, J., 2000. Towards Industrial Ecology: Sustainable Development as a Concept of Ecological Modernization. Journal of Environmental Policy and Planning. 2, 269-285. 
Huber, J., 2008. Pioneering Countries and the Global Diffusion of Environmental Innovations: These from the Viewpoint of Ecological Modernisation Theory. Global Environmental Change. 18, 360-367.

Janicke, M. and Jacob, K., 2004. Lead Markets for Environmental Innovations: A New Role for the Nation State. Global Environmental Politics. 4(1), 29-46.

Janicke, M., 2008. Ecological Modernisation: New Perspectives. Journal of Cleaner Production. 16, 557-565.

Kaswan, A. 2008. Environmental Justice and Domestic Climate Change Policy. Environmental Law Reporter. 38, 10287-10315.

Lloyd-Smith, M. E. and Bell, L., 2003. Toxic Disputes and the Rise of Environmental Justice in Australia. International Journal of Occupational and Environmental Health. 9, 14-23.

McInnes, K. L., Hubbert, G. D., Oliver, S. and Abbs, D., 2000. Gold Coast Broadwater Study: Storm Tide Return Periods and 1974 Stormwater Modelling. CSIRO Atmospheric Research and Global Environmental Modelling Systems.

McMichael, A.J., Woodruff, R.E., Whetton, P. Hennessy, K., Nicholls, N., Hales, S.,Woodward, A. and Kjellstrom, T., 2003. Human Health and Climate Change in Oceania: A Risk Assessment. Canberra: Australian Government Department of Health and Ageing.

Mendelsohn, R., Dinar, A. and Williams, L., 2006. The Distributional Impact of Climate Change on Rich and Poor Countries. Environment and Development Economics. 11, 159-178.

Mol A. and Sonnenfeld D., 2000. Ecological Modernisation around the World: An Introduction. Environmental Politics. 9 (1), 3-14.

Mol A. and Spaargaren G., 2000. Ecological Modernisation. Environmental Politics. $9(1), 17-49$.

Mol A., 2000. The Environmental Movement in an Era of Ecological Modernisation. Geoforum. 31, 45-56.

Office of Climate Change [OCC], 2008. Climate Change in Queensland: What the Science is Telling Us. Brisbane, Australia: Environmental Protection Agency, Queensland Government.

Office of Urban Management [OUM], 2005. South East Queensland Regional Plan 2005-2026. Brisbane: Queensland Government.

Queensland Water Commission [QWC], 2009. Revised Draft South East Queensland Water Strategy. Brisbane: Queensland Government.

Reyenga, P.J., Howden, S.M., Meinke, H., and McKeon, G.M., 1999. Modelling Global Change Impacts on Wheat Cropping in South-East Queensland, Australia. Environmental Modelling \& Software. 14, 297-306.

Ruth, M., ed., 2006. Smart Growth and Climate Change: Regional Development, Infrastructure and Adaptation. Northampton, Mass: Edward Elgar Publishing.

Salick, J., Byg, A., Silveira, A., Moura, R. and Andrade, N., 2007. Indigenous Peoples and Climate Change. Aidis; Asociación Interamericana De Ingeniería Sanitaria $Y$ Ambiental. Sección Uruguay. Rescatando Antiguos Principios Para Los Nuevos Desafíos Del Milenio. Montevideo: Aidis, 2006, 1-8 Mapas, Tab.

Shiva, V., 1999. Ecological Balance in an Era of Globalization. In: N. Low, ed. Global Ethics and Environment. London: Routledge, 47-69.

Shonkoff, S., Morello-Frosch, R., Pastor, M. and Sadd, J., 2009. Minding the Climate Gap: Environmental Health and Equity Implications of Climate Change Mitigation Policies in California. Environmental Justice. 2, 173-177. 
South East Queensland Healthy Waterways Partnership [SEQHWP], 2007. The South East Queensland Healthy Waterways Strategy 2007-2012. Canberra: Australian Government.

Sweetman, C. 2009. Introduction. Gender \& Development. 17, 1-3.

Taylor, D., 2000. The Rise of the Environmental Justice Paradigm. American Behavioral Scientist. 43, 508-580.

Thomas, I., 2010. Environmental Policy and Local Government in Australia. Local Environment. 15, 121-136.

Weale A., 1998. The Politics of Ecological Modernization. In: J. Dryzek \& D. Schlosberg, eds. Debating the Earth: The Environmental Politics Reader. Oxford: Oxford University Press, 301-318.

Welford R, and Hills P., 2004. Ecological Modernisation, environmental policy and innovation priorities for the Asia-Pacific Region. International Journal of Environment and Sustainable Development, 2 (3), 324-340. 


\section{Adaptation Strategies}

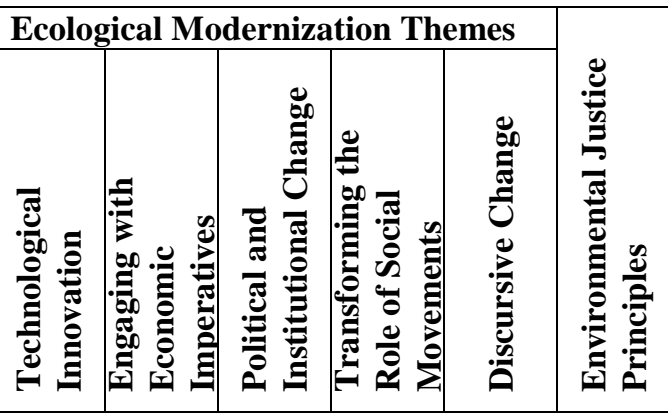

Principle 1.4. Increase the resilience of communities, development, essential infrastructure, natural environments and economic sectors to natural hazards including the projected effects of climate change. Policy 1.4.1 Reduce natural hazard (NH) risk by avoiding high exposure areas and establishing adaptation strategies. Policy 1.4.2 Reduce NH risk by establishing strategies to minimise heatwave, cyclone \& storm vulnerability and rainfall variability risks. Policy 1.4.3 Planning to comply with the Queensland Coastal Plan, including rising sea levels.

Program 1.4.4 Use SEQ Climate Change Management Plan to increase resilience to \& reduce natural hazard risks.

Program 1.4.5 Develop planning and design performance criteria for natural hazards \& climate change risk management.

Principle 2.1. Protect, manage and enhance the region's biodiversity values and associated ecosystem services and maximise the resilience of ecosystems to the impacts of climate change.

Policy 2.1.1 Avoid significant biodiversity impacts in the Regional Landscape and Rural Production Area.

Policy 2.1.2 Avoid or minimise significant biodiversity impacts on Urban Footprint or Rural Living Area.

Policy 2.1.3 Avoid offsite impacts from development on areas with significant biodiversity values.

Policy 2.1.4 Where impacts cannot be avoided, offset them according to the Queensland Government Environmental Offsets Policy.

Policy 2.1.5 Protect significant biodiversity values within biodiversity networks, improve connectivity, enhance habitat \& rehabilitate areas. Policy 2.1.6 Optimise biodiversity conservation by locating environmental \& carbon offsets within identified bio-networks.

Program 2.1.7 Identify and manage regional and local biodiversity networks in partnership with private and public landholders.

Program 2.1.8 Share and coordinate information about biodiversity networks within the open space network at regional and local scales. Program 2.1.9 Take actions to achieve nature conservation targets in the SEQ Natural Resource Management Plan 2009-2031.

Program 2.1.10 Via stakeholder consultation, develop \& implement regional framework to coordinate offset policies and programs.

Program 2.1.11 Integrate an agreed biodiversity mapping approach for the region, for use in state, regional and local planning.

Principle 2.4 Maintain, protect and enhance the values of the region's coast, including the foreshore, coastal wetlands, dunes, coastal processes, marine ecosystems, significant coastal values and marine waters.

Policy 2.4.1 Locate, design and manage coastal development to avoid or mitigate adverse effects on coastal values.

Policy 2.4.2 Ensure development avoids erosion prone areas, inundation hazard areas, \& undeveloped sections of tidal waterways. Policy 2.4.3 Ensure that development on the coast maintains natural physical coastal processes.

Policy 2.4.4 Maintain and enhance safe public access to the foreshore design public access to conserve coastal resources.

\begin{tabular}{|l|l|l|l|l|l|} 
& $\mathbf{P}$ & & & & $\mathbf{M}$ \\
\hline $\mathbf{P}$ & $\mathbf{P}$ & & & & $\mathbf{I}$ \\
& & & & & \\
\hline & & $\mathbf{P}$ & & & $\mathbf{I}$ \\
\hline & & & & & $\mathbf{I}$ \\
\hline
\end{tabular}

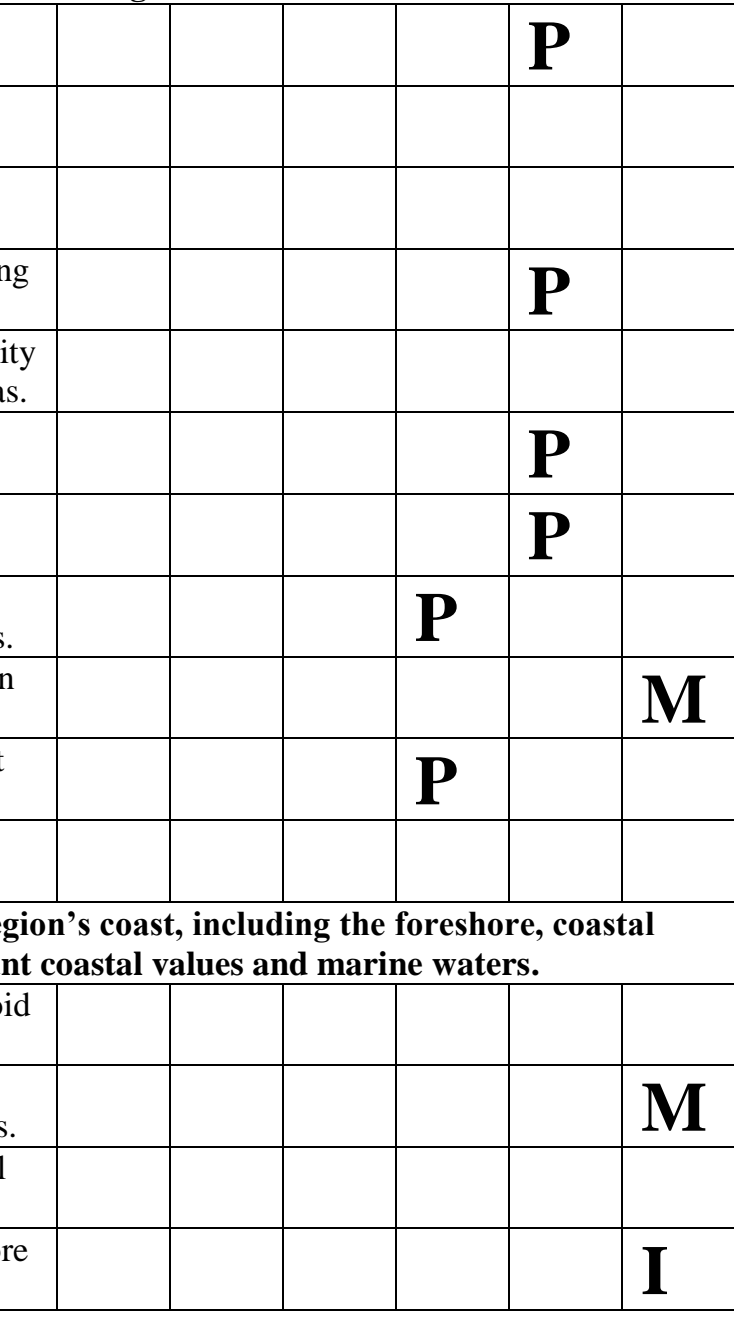




\begin{tabular}{|l|l|l|l|l|}
\hline & & & \\
\end{tabular}
* E: Explicit
I: Implied
M: Marginal
P: Potential 


\begin{tabular}{|c|c|c|c|c|c|c|}
\hline \multirow[b]{2}{*}{ Adaptation Strategies } & \multicolumn{5}{|c|}{ Ecological Modernization Themes } & \multirow[b]{2}{*}{ 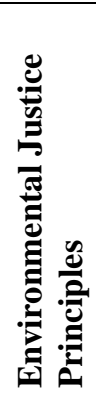 } \\
\hline & \multirow[t]{2}{*}{ 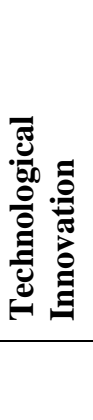 } & 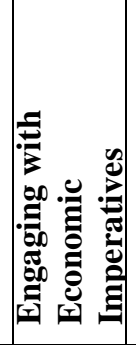 & 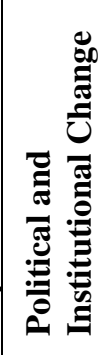 & 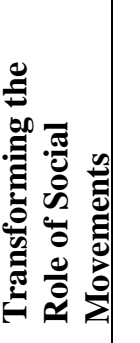 & 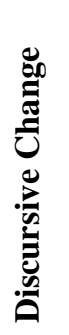 & \\
\hline $\begin{array}{l}\text { Program K. Reinforce \& enhance government directives to reduce } \\
\text { community \& infrastructure exposure to coastal hazards. }\end{array}$ & & $\mathbf{P}$ & & & & $\mathbf{M}$ \\
\hline $\begin{array}{l}\text { Draft action 20. Prepare a new Queensland Coastal Plan and } \\
\text { supporting guidelines. }\end{array}$ & & & & & & \\
\hline $\begin{array}{l}\text { Draft action } 21 . \text { Update the current guideline, Mitigating adverse } \\
\text { impacts of storm tide inundation to incorporate new climate science. }\end{array}$ & & & & & & \\
\hline $\begin{array}{l}\text { Draft action 22. Implement new Queensland Coastal Plan policies via } \\
\text { regional \& local planning \& infrastructure decision-making. }\end{array}$ & & & & & & \\
\hline $\begin{array}{l}\text { Draft action 23. Acquire fine-scale digital elevation data for coastal } \\
\text { areas for use in assessing risk and mapping hazard-prone areas. }\end{array}$ & & & & & & \\
\hline $\begin{array}{l}\text { Draft action 24. Prepare and publish regional and local-scale risk } \\
\text { assessments and maps of coastal hazard areas in new Coastal Plan. }\end{array}$ & & & & & & \\
\hline $\begin{array}{l}\text { Program L. Reinforce government directives, guidance \& mapping to } \\
\text { reduce community, development \& infrastructure vulnerability. }\end{array}$ & & & & & & \\
\hline $\begin{array}{l}\text { Draft action 25. Review and update State Planning Policy (SPP) } \\
1 / 03-\text { Mitigating the Adverse Impacts of Flood, Bushfire and } \\
\text { Landslide, and develop supporting guidelines. }\end{array}$ & & & & & & \\
\hline $\begin{array}{l}\text { Draft action 26. Develop SPP guidelines for hazard \& risk mapping } \\
\text { including projected effects of climate change on natural hazards. }\end{array}$ & & & & & & \\
\hline $\begin{array}{l}\text { Draft action 27. Develop a regional summary of projected climate } \\
\text { change impacts for SEQ. }\end{array}$ & & & & & & \\
\hline $\begin{array}{l}\text { Draft action 28. Prepare local-scale climate-resilient urban planning } \\
\text { and design guidelines and performance criteria for sensitive areas. }\end{array}$ & & & & & & \\
\hline $\begin{array}{l}\text { Program M. Reinforce and enhance research knowledge, and } \\
\text { government directives to build ecosystem resilience. }\end{array}$ & $\mathbf{P}$ & & & & & \\
\hline $\begin{array}{l}\text { Draft action 29. Improve understanding of the vulnerability of } \\
\text { ecosystems to climate change. }\end{array}$ & & & & & & \\
\hline $\begin{array}{l}\text { Draft action 30. Prepare regional and local adaptation strategies to } \\
\text { mitigate impacts of climate change on natural ecosystems. }\end{array}$ & & & & & & \\
\hline $\begin{array}{l}\text { Program N. Reinforce and enhance government applications of } \\
\text { research knowledge about climate change adaptation in SEQ. }\end{array}$ & & & & & & $\mathbf{M}$ \\
\hline $\begin{array}{l}\text { Draft action } 31 \text {. Facilitate SEQ local governments \& state agencies to } \\
\text { uptake climate change research. }\end{array}$ & & & $\mathbf{D}$ & & & \\
\hline $\begin{array}{l}\text { Program O. Increase community awareness and influence behaviour } \\
\text { regarding climate change in SEQ. }\end{array}$ & & & & $\mathbf{P}$ & & \\
\hline $\begin{array}{l}\text { Draft action } 32 \text {. Develop and implement a communications strategy } \\
\text { to build resilience to projected effects of climate change in SEQ. }\end{array}$ & & & & $\mathbf{D}$ & & \\
\hline
\end{tabular}

* E: Explicit I: Implied M: Marginal P: Potential 